\title{
ROBOT IP NETWORK (ROBIN) YANG DIKENDALIKAN MELALUI WEBSITE
}

\author{
Asep Saefullah ${ }^{1}$ \\ Sudaryono ${ }^{2}$ \\ Cristian $\mathrm{BMS}^{3}$ \\ E-mail: asepsaepullah@pribadiraharja.com,sudaryono@faculty.raharja.ac.id \\ cristianBMS@yahoo.com
}

Diterima :8 Juli 2010/Disetujui : 23 Juli 2010

\begin{abstract}
Basically, the robot can do the work in accordance with programs included in the 'chip' as the brain. In general, the robot control system is in place where the robot is located. The problem is what if the owner of the robots are at different distances even owned the continent with a robot but should still be able to control the robots. With the development of information technology and the challenge of long distance communication control system (control system remotely), the robot as one icon automation system can be controlled not only locally but can be controlled remotely using the internet network. For remote controlling the project developed a robot that can be controlled from a computer (laptop / notebook) via the internet network and named ROBIN (Robot IP Network). Control interface is done through the website to move the robot forward, backward, left and right. HTML-based Web control was made with flash and javascript. Utilizing a wireless communication access point placed on the robot. TCP / IP Starter Kit as a liaison between the robots functioning website to translate commands sent by the web to be executed microcontroller. Between the robot and the controller (Laptop / Notebook), respectively were given the identity of the address so they can communicate with each other. ROBIN is a prototype robot that controlled movement of a website through the Internet.
\end{abstract}

Keyword : ROBIN, robot IP, robot network

1. Dosen Jurusan Sistem Komputer, STMIK Raharja

J1. Jend. Sudirman No. 40 Cikokol - Tangerang Telp. 5529692

2. Dosen Jurusan Sistem Komputer, STMIK Raharja

Jl. Jend. Sudirman No. 40 Cikokol - Tangerang Telp. 5529692

3. Mahasiswa Jurusan Sistem Komputer, STMIK Raharja

Jl. Jend. Sudirman No. 40 Cikokol - Tangerang Telp. 5529692 


\section{ABSTRAK}

Robot mampu mengerjakan tugas sesuai dengan program yang dimasukkan ke dalam 'chip' sebagai otaknya. Secara umum, sistem kendali robot dilakukan ditempat di mana robot itu berada. Permasalahannya adalah bagaimana jika pemilik robot berada pada jarak yang jauh bahkan berbeda benua dengan robot yang dimiliki tetapi harus tetap bisa untuk mengendalikan robot tersebut. Dengan perkembangan teknologi informasi dan komunikasi menjawab tantangan long distance control system (pengendalian sistem jarak jauh), robot sebagai salah satu icon sistem otomasi tidak hanya dapat dikendalikan secara lokal tetapi mampu dikontrol jarak jauh (remote) dengan menggunakan jaringan internet. Untuk pengontrolan jarak jauh dikembangkan proyek robot yang dapat dikendalikan dari komputer (laptop / notebook) melalui jaringan internet yang diberinama ROBIN (Robot IP Network). Interface pengontrolan dilakukan melalui website untuk menggerakkan robot maju, mundur, kiri dan kanan. Web control dibuat berbasis HTML dilengkapi dengan flash dan javascript. Komunikasi wireless memanfaatkan access point yang di tempatkan pada robot. TCP/IP Starter Kit sebagai penghubung antara website dengan robot berfungsi menerjemahkan perintah yang dikirimkan oleh web untuk dieksekusi mikrokontroller. Antara robot dan pengontrol (Laptop / Notebook), masing - masing diberikan alamat identitas sehingga keduanya dapat saling berkomunikasi. ROBIN merupakan sebuah prototype robot yang pergerakannya dikontrol sebuah website melalui jaringan internet.

Kata Kunci : ROBIN, robot IP, robot network

\section{PENDAHULUAN}

Otomatisasi merupakan bentuk pengendalian sistem yang mulai mengurangi campur tangan manusia, sehingga Human Error atau tingkat kesalahan yang disebabkan oleh manusia dapat ditekan. Dalam dunia industri otomatisasi sangat dibutuhkan untuk melakukan tugas yang butuh ketelitian ekstra dan kondisi yang ekstrem. Contohnya, pada pemasangan komponen elektronika yang sedemikian kecil sehingga membutuhkan tingkat ketepatan yang tinggi, itu akan sangat sulit jika dikerjakan oleh manusia. Contoh yang lain adalah penggunaan robot untuk melakukan tugas-tugas berat dan lingkungan yang tidak bisa dijangkau manusia, seperti dalam bidang pertambangan, nuklir, industri baja dan banyak hal lain. Dalam kehidupan rumah tanggapun peranan otomatisasi dan robot mulai diperkenalkan untuk membantu aktivitas manusia, seperti robot-robot humanoid yang membantu tugas pekerjaan rumah tangga.

Robot mampu mengerjakan tugas sesuai dengan program yang dimasukkan ke dalam Chips sebagai otaknya. Secara umum, sistem kendali atas kinerja dari 
robot dilakukan di tempat di mana robot itu berada. Permasalahannya adalah bagaimana jika pemilik robot berada pada jarak yang jauh bahkan berbeda benua dengan robot yang dimiliki tetapi harus tetap bisa mengendalikan robot tersebut. Perkembangan teknologi informasi dan komunikasi mampu menjawab tantangan ini. Seiring dengan perkembangan kebutuhan manusia, jaringan internet tidak hanya digunakan untuk mengakses file atau informasi saja tetapi mampu digunakan untuk kendali sistem otomasi jarak jauh. Gabungan antara teknologi informasi, komunikasi dan juga otomasi khususunya robot melahirkan CCIT (Creative Communication and Innovative Technology) yang dikembangkan oleh dosen dan mahasiswa Jurusan Sistem Komputer STMIK Raharja. Dengan teknologi ini sistem otomasi dengan menggunakan robot akan menjadi lebih istimewa karena mampu dikendalikan kapanpun dan dimanapun selama jaringan internet ada maka ROBIN dapat dikontrol.

\section{METODOLOGI}

Dalam perancangan ROBIN maka dilakukan langkah-langkah sebagai berikut :

1. Studi pustaka/internet searching tentang peralatan pendukung ROBIN yang fokus kepada komunikasi antara mikrokontroler dengan TCP/IP starter kit, diperlukan sebuah CPU atau chip yang berfungsi sebagai otak dari sistemnya. CPU ini bisa menggunakan mikroprosesor, mikrokontroler, atau gabungan antar keduanya. Berbagai vendor telah tersedia di pasaran seperti : Atmel, Microchip, NI(National Instruments), Intel dan masih banyak lainnya.

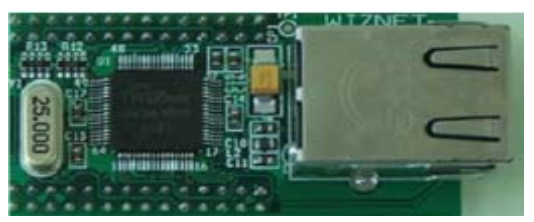

\section{Gambar 1. TCP/IP Starter Kit NM7010A}

2. Cross compiler, setelah tersedianya peralatan pendukung ROBIN langkah berikutnya adalah menuliskan dan mengcompile program. Cross compiler merupakan compiler yang dapat berjalan pada satu jenis komputer dan dapat menerjemahkan pada berbagai jenis komputer yang berbeda.

3. Cross develoment tools, setelah program dicompile berikutnya diuji dengan simulator atau emulator. Hasil dari pengujian ini di masukan ke dalam memori microcontroller. Simulator merupakan sebuah program perangkat lunak yang 
akan menjalankan sebuah rancangan program untuk satu buah jenis devices, simulator akan memperlihatkan hasil sebuah program yang akan mengendalikan suatu devices. Emulator merupakan sebuah perangkat keras seperti sebuah target machine, paket emulator biasanya disertakan display program untuk menguji register dan lokasi memori.

Adapun tahapan-tahapan dalam ROBIN adalah sebagai berikut :

a. Membuat spesifikasi masalah

b. Pemilihan peralatan atau chip microcomputer

c. Perancangan perangkat lunak

d.Perancangan peralatan

e. Melakukan coding

f. Proses pengujian dan diakhiri dengan pengintegrasian antara software dan hardware

\section{HASIL DAN PEMBAHASAN}

\section{Perangkat Keras ROBIN}

Perancangan Robot IP Network (ROBIN) dapat di jelaskan dengan blok diagram seperti gambar berikut :

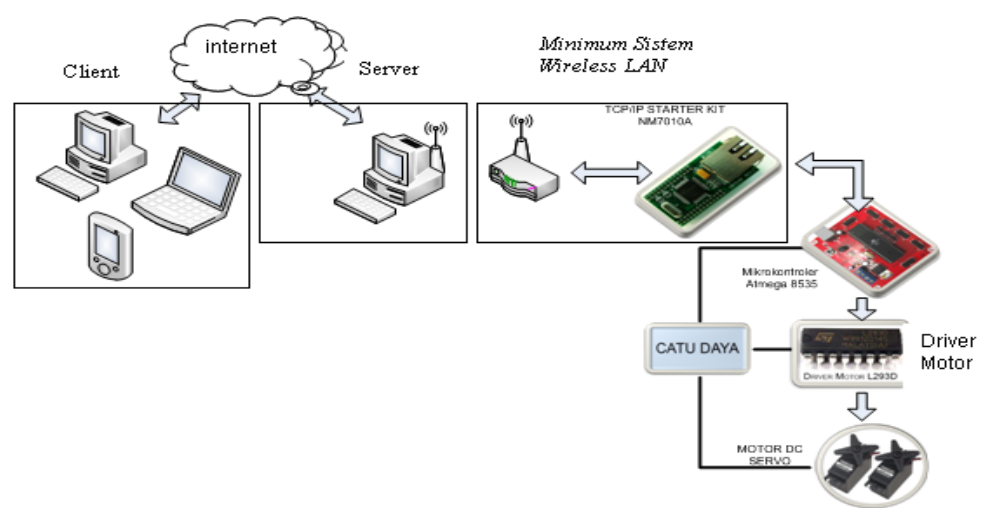

Gambar 2. Blok Diagram Perancangan ROBIN 
Rancangan dengan menggunakan Mikrokontroler AVR Atmega 8535, dengan menggunakan Mikrokontroler jenis ini outputnya dapat secara langsung digunakan untuk menjalankan Driver atau penggerak motor servo. Sehingga robot dapat bergerak seperti yang kita inginkan, maju kedepan, belok kanan, belok kiri dan mundur ke belakang.

Dalam pengontrolan Robot ini, bisa digunakan notebook / PC (personal komputer) digunakan untuk Client dan server, dengan spesifikasi yang harus dipenuhi adalah mempunyai Koneksi jaringan internet, dan untuk Server harus mempunyai Wireless atau wifi.

\section{Acces Point}

Acces Point digunakan untuk pengiriman sinyal secara Wireless dari TC/IP Starter Kit, agar bisa di tangkap oleh Notebook ataupun Personal Computer yang sudah dilengkapi Wireless Adapter standar $802.11 \mathrm{~b} / \mathrm{g}$. Wireless Acces Point yang digunakan adalah D-Link DWL-2100AP.

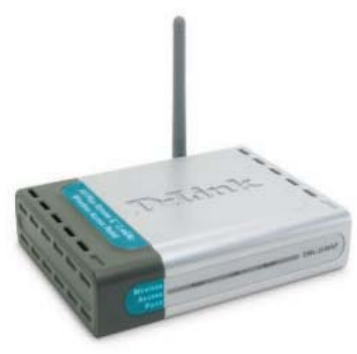

Gambar 3. Bentuk fisik D-Link DWL-2100AP

( http://www.dlink.com/products/?pid=292)

Selain berfungsi sebagai Access Point, D-Link DWL-2100AP dapat juga diposisikan sebagai repeater (penguat sinyal dari access point lain). Demikian pula, terdapat fitur untuk mengatur sensitivitas transmisi sinyal. Fasilitas load balancing bermanfaat untuk membatasi jumlah klien yang terhubung agar beban kerja access point tidak melewati batas. D-Link DWL-2100AP dapat diatur agar tidak memancarkan (broadcast) sinyal identitas keberadaannya (SSID), sehingga tidak terdeteksi oleh aplikasi site survey. Hal ini bermanfaat sebagai upaya pengamanan agar akses ilegal dapat ditekan. Fitur pengamanan tambahan yang tidak kalah penting adalah MAC address filter untuk menyaring nomor-nomor alamat kartu jaringan yang diijinkan atau yang tidak diijinkan mengakses jaringan. Terlalu riskan, jika membiarkan lalu-lintas paket data yang melewati access point tidak terlindungi. 
Maka, D-Link DWL-2100AP menyediakan enkripsi (pengacakan) dengan standar WEP, WPA, WPA2 serta WPA2-PSK. Wireless Access Point ini membutuhkan daya input Power DC 5V, 2.0A, dan menghasilkan sinyal Wireless $15 \mathrm{dBm}(32 \mathrm{~mW})$ $\pm 2 \mathrm{~dB}$. Bekerja dengan Range frekuensi Wireless 2,4 Ghz-2,4835Ghz.

\section{TCP/IP Starter Kit}

Embedded Ethernet merupakan implementasi standar jaringan dari Ethernet pada sebuah single-chip. Secara sederhana, dengan menanamkan Ethernet ke sebuah alat, akan memberikan sebuah kemampuan untk berkomunikasi lewat Ethernet tanpa menggunakan sebuah komputer. Embedded Ethernet berfungsi sebagai interface antara mikrokontroler dengan jaringan komputer yang ada. ROBIN menggunakan chip embedded Ethernet produksi Wiznet dengan seri W3100A. Chip ini terintegrasi dengan ethernet $\mathrm{PHY}$, dan mag jack sebagai soket female RJ45 pada sebuah network module. Chip ini memiliki TCP/IP protokol stack seperti TCP, UDP, IP, ARP dan protokol ICMP.

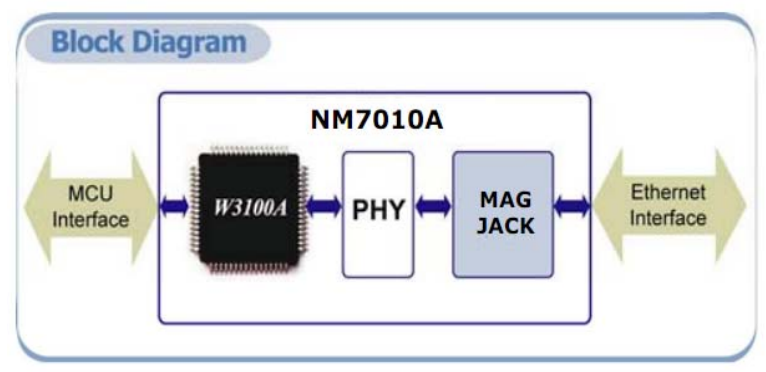

Gambar 4. Diagram Blok Network Module NM7010A

Network Module NM7010A-LF, secara teknis mendukung 10/100 base Tx, halfffull duplex, dan auto negotiation, produk ini sudah sesuai dengan standar IEEE 802.3/80.3u, dan membutuhkan catu daya 3,3 V dengan I/O 5V Tolerance. Bisa menggunakan antarmuka $I^{2} C$ dan bus Intel/Motorola dengan akses direct/ indirect, Mendukung mode clocked, non-clocked, external clocked, dan juga mendukung socket API untuk mudah pemrograman aplikasi. Jika jalur komunikasi IC diparalel (cascade) dengan modul atau IC berantar muka IC lain, pastikan bahwa pin I/O modul atau IC tersebut toleran terhadap 5V (5VI/O). Jika modul atau IC $\mathrm{I}^{2} \mathrm{C}$ tersebut menggunakan tegangan kerja 3,3V, maka gunakan $\mathrm{R}$ pull-up pada $\mathrm{TCP} / \mathrm{IP}$ Starter Kit. Jika modul atau IC I ${ }^{2} \mathrm{C}$ tersebut menggunakan tegangan kerja 
5V, maka R pull-up (R16 dan R17) pada TCP/IP Starter Kit dapat dilepas (dengan solder) dan gunakan $\mathrm{R}$ pull-up pada modul atau IC $\mathrm{I}^{2} \mathrm{C}$ tersebut.

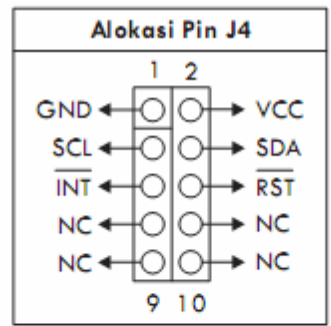

\begin{tabular}{|c|c|l|}
\hline Pin & I/O & \multicolumn{1}{|c|}{ Fungsi } \\
\hline GND & - & Titik referensi ground \\
\hline VCC & - & Terhubung ke sumber tegangan (5 Volt) \\
\hline SCL & 1 & Serial Clock \\
\hline SDA & $1 / O$ & Serial Data \\
\hline INT & 0 & $\begin{array}{l}\text { Interrupt, berlogika Low setelah adanya } \\
\text { penerimaan atau pengiriman data. }\end{array}$ \\
\hline RST & 1 & $\begin{array}{l}\text { Reset, diberi logika Low selama } 10 \mathrm{~ms} \\
\text { untuk melakukan reset terhadap modul } \\
\text { TCP/IP Starter Kit }\end{array}$ \\
\hline
\end{tabular}

Gambar 5. Pin J4 TCP/IP Starter Kit dan fungsinya

Alamat $\mathrm{I}^{2} \mathrm{C}$ dari modul jaringan NM107A dapat diatur menggunakan DIP Switch D3.

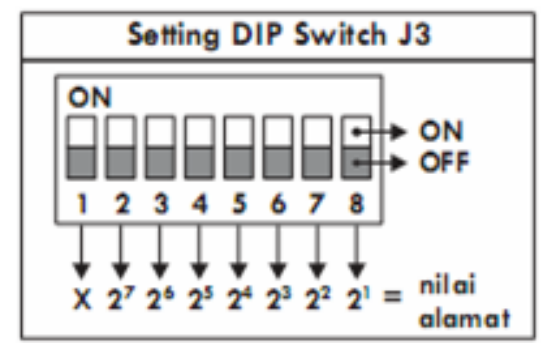

Gambar 6. DIP Switch J3 TCP/IP Starter Kit

Alamat $\mathrm{I}^{2} \mathrm{C}$ ditentukan oleh posisi saklar 2 - saklar 8, sedangkan saklar 1 tidak digunakan. Nilai alamat didapatkan dengan menjumlahkan nilai saklar yang berada 
pada posisi OFF. Misalnya saklar 2, 3,6, pada posisi OFF dan saklar 4, 5, 7 pada posisi ON maka alamat modul adalah: $2+2+2+2=202$ (desimal )atau CA (heksadesimal). Kondisi LED (COL/LINK, 10/100 ACT, dan DUPX) mencerminkan konektivitas jaringan modul TCP/IP Starter Kit sebagai berikut:

\begin{tabular}{|c|c|c|c|}
\hline \multirow{2}{*}{ LED } & \multicolumn{2}{|c|}{ Kondisi } & \multicolumn{2}{|c|}{ Menyala } & \multirow{2}{*}{ Padam } \\
\cline { 2 - 3 } & Oranye & Hijau & \\
\hline COL/LINK & Collision & Link & - \\
\hline $10 / 100 \mathrm{ACT}$ & $10 \mathrm{Mbps}$ & $100 \mathrm{Mbps}$ & No activity \\
\hline DUPX & - & Full duplex & Half duplex \\
\hline
\end{tabular}

Tabel 1. Kondisi LED indikator

TCP/IP Starter Kit dapat dihubungkan dengan Network Adapter pada komputer yang memiliki konektor MAC jack dengan menggunakan kabel UTP yang kedua ujungnya diberi terminasi RJ-45 (8P8C Modular Connector).

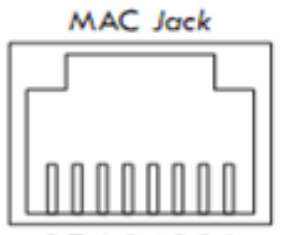

87654321

\begin{tabular}{|c|c|c|}
\hline \multirow{2}{*}{ Pin } & \multicolumn{2}{|c|}{ Warna Kabel } \\
\cline { 2 - 3 } & Konfigurasi 1 & Konfigurasi 2 \\
\hline 1 & Putih Hijau & Putih Oranye \\
\hline 2 & Hijou & Oranye \\
\hline 3 & Putih Oranye & Putih Hijou \\
\hline 4 & Biru & Biru \\
\hline 5 & Putih Biru & Putih Biru \\
\hline 6 & Oranye & Hijau \\
\hline 7 & Putih Coklat & Putih Coklat \\
\hline 8 & Coklat & Coklat \\
\hline
\end{tabular}

Gambar 7. Konektor MAC jack dan warna kabel

Kabel UTP yang disertakan bertipe "Crossover" dan dapat digunakan sebagai koneksi ke komputer. Pada tipe" Crossover", salah satu ujung kabel diberi terminasi RJ-45 berkonfigurasi 1 sedangkan ujung kabel yang lain diberi terminasi RJ-45 berkonfigurasi 2. Sedangkan untuk menghubungkan TCP/IP Starter Kit ke hub/router biasany amenggunakan kabel UTP bertipe "Straight-Through". Pada 
tipe “Straight-Through", kedua ujung kabel diberi terminasi RJ-45 berkonfigurasi 1 semua atau berkonfigurasi 2 semua.

\section{Sistem Minimum Mikrokontroler}

Sistem minimum(sismin) mikrokontroler adalah rangkaian elektronik minimum yang diperlukan untuk beroperasinya IC mikrokontroler. Sismin ini kemudian bisa dihubungkan dengan rangkaian lain untuk menjalankan fungsi tertentu. Di keluarga mikrokontroler AVR, seri 8535 adalah salah satu seri yang sangat banyak digunakan. Untuk membuat rangkaian sismin Atmel AVR 8535 diperlukan beberapa komponen yaitu:

1. IC mikrokontroler ATmega8535

2. 1 XTAL $4 \mathrm{MHz}$ atau $8 \mathrm{MHz}$ (XTAL1)

3. 3 kapasitor kertas yaitu dua $22 \mathrm{pF}(\mathrm{C} 2$ dan $\mathrm{C} 3)$ serta $100 \mathrm{nF}(\mathrm{C} 4)$

4. 1 kapasitor elektrolit $4.7 \mathrm{uF}(\mathrm{C} 12) 2$ resistor yaitu $100 \mathrm{ohm}(\mathrm{R} 1)$ dan 10 Kohm (R3)

5. 1 tombol reset pushbutton (PB1)

Rangkaian sistem minimum ini sudah siap untuk menerima sinyal analog (fasilitas ADC) di port A. Gambar rangkaiannya adalah sebagai berikut.

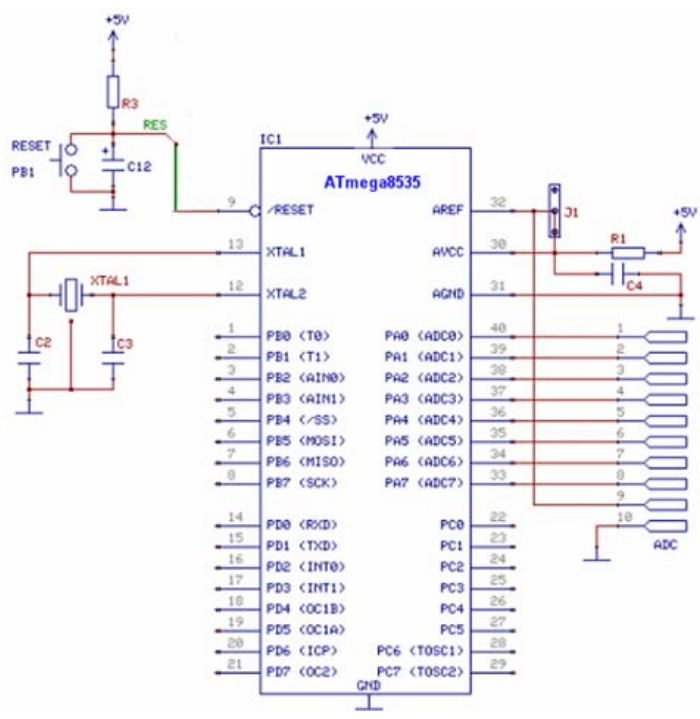

Gambar 8. Rangkaian sistem minimum AVR 8535 


\section{Keterangan Pin ATMega8535}

\section{PortA}

Merupakan 8-bit directional port I/O. Setiap pinnya dapat menyediakan internal pull-up resistor (dapat diatur per bit). Output buffer Port A dapat memberi arus $20 \mathrm{~mA}$ dan dapat mengendalikan display LED secara langsung. Data Direction Register port A(DDRA) harus disetting terlebih dahulu sebelum Port A digunakan. Bit-bit DDRA diisi 0 jika ingin memfungsikan pin-pin port A yang bersesuaian sebagai input, atau diisi 1 jika sebagai output. Selain itu, kedelapan pin port A juga digunakan untuk masukan sinyal analog bagi A/D converter.

\section{Port B}

Merupakan 8-bit directional port I/O. Setiap pinnya dapat menyediakan internal pull-up resistor (dapat diatur per bit). Output buffer Port $\mathrm{B}$ dapat memberi arus $20 \mathrm{mAdan}$ dapat mengendalikan display LED secara langsung. Data Direction Register port $\mathrm{B}$ (DDRB) harus disetting terlebih dahulu sebelum Port B digunakan. Bit-bit DDRB diisi 0 jika ingin memfungsikan pin-pin port $B$ yang bersesuaian sebagai input, atau diisi 1 jika sebagai output. Pin-pin port B juga memiliki untuk fungsifungsi alternatif khusus seperti yang dapat dilihat dalam tabel berikut.

\begin{tabular}{|l|l|}
\hline Port Pin & \multicolumn{1}{c|}{ Fungsi Khusus } \\
\hline PB0 & T0 = timer/counter 0 external counter input \\
\hline PB1 & T1 = timer/counter 0 external counter input \\
\hline PB2 & A1N0 = analog comparator positive input \\
\hline PB3 & A1N1 = analog comparator negative input \\
\hline PB4 & SS = SPI slave select input \\
\hline PB5 & MOSI = SPI bus master output $/$ slave input \\
\hline PB6 & MISO = SPI bus master input $/$ slave output \\
\hline PB7 & SCK $=$ SPI bus serial clock \\
\hline
\end{tabular}

Tabel 2. Fungsi alternatif khusus Pin Port B

Port Pin

Fungsi Khusus

PB0 T0 $=$ timer/counter 0 external counter input

PB1 T1 = timer/counter 0 external counter input

PB2 $\quad \mathrm{A} 1 \mathrm{N0}=$ analog comparator positive input

PB3 A1N1 = analog comparator negative input

PB4 SS = SPI slave select input 
PB5 $\quad$ MOSI = SPI bus master output $/$ slave input

PB6 $\quad \mathrm{MISO}=$ SPI bus master input / slave output

PB7 $\quad$ SCK $=$ SPI bus serial clock

\section{Port C}

Merupakan 8-bit directional port I/O. Setiap pinnya dapat menyediakan internal pull-up resistor (dapat diatur per bit). Output buffer Port $\mathrm{C}$ dapat memberi arus $20 \mathrm{~mA}$ dan dapat mengendalikan display LED secara langsung. Data Direction Register port $\mathrm{C}(\mathrm{DDRC})$ harus disetting terlebih dahulu sebelum Port $\mathrm{C}$ digunakan. Bit-bit DDRC diisi 0 jika ingin memfungsikan pin-pin port $C$ yang bersesuaian sebagai input, atau diisi 1 jika sebagai output. Selain itu, dua pin port C (PC6 dan PC7) juga memiliki fungsi alternatif sebagai oscillator untuk timer/counter 2 .

\section{Port D}

Merupakan 8-bit directional port I/O. Setiap pinnya dapat menyediakan internal pull-up resistor (dapat diatur per bit). Output buffer Port $\mathrm{D}$ dapat memberi arus 20 mA dan dapat mengendalikan display LED secara langsung. Data Direction Register port D(DDRD) harus disetting terlebih dahulu sebelum Port D digunakan. Bit-bit DDRD diisi 0 jika ingin memfungsikan pin-pin port $D$ yang bersesuaian sebagai input, atau diisi 1 jika sebagai output. Selain itu, pin-pin port D juga memiliki untuk fungsi-fungsi alternatif khusus seperti yang dapat dilihat dalam tabel berikut :

\begin{tabular}{|l|l|}
\hline Port Pin & \multicolumn{1}{|c|}{ Fungsi Khusus } \\
\hline PD0 & RDX (UART input line) \\
\hline PD1 & TDX (UART output line) \\
\hline PD2 & INT0 (External interrupt 0 input) \\
\hline PD3 & INT1 (External interrupt 1 input) \\
\hline PD4 & $\begin{array}{l}\text { OC1B (Timer/Counter 1 output compare B match } \\
\text { output) }\end{array}$ \\
\hline PD5 & $\begin{array}{l}\text { OC1A (Timer/Counter 1 output compare A } \\
\text { match output) }\end{array}$ \\
\hline PD6 & ICP (Timer/Counter 1 input capture pin) \\
\hline PD7 & $\begin{array}{l}\text { OC2 (Timer/Counter 2input compare match } \\
\text { output) }\end{array}$ \\
\hline
\end{tabular}

Tabel 3. Fungsi alternatif khusus Pin Port D 
Port Pin

PD0 RDX(UART input line)

PD1 TDX (UART output line)

PD2 INT0 (External interrupt 0 input)

PD3 INT1 (External interrupt 1 input)

PD4 OC1B (Timer/Counter 1 output compare B match output)

PD5 OC1A(Timer/Counter 1 output compare A match output)

PD6 ICP(Timer/Counter 1 input capture pin)

PD7 OC2 (Timer/Counter 2input compare match output)

Rangkaian mikrokontroler ini merupakan tempat pengolahan data dan pengoperasian alat. Dan dalam rancangan ini, mikrokontroler berfungsi sebagai otak dari seluruh sistem rancangan. Mikrokontroler AVR 8535 ini memiliki empat buah port dan berbagai pin yang digunakan untuk menampung input atau output data dan terhubung langsung dengan rangkaian-rangkaian dari alat TCP/IP Starter Kit.

Pembagian fungsi dari tiap-tiap port sebagai berikut:

1) Port A.0, digunakan untuk mengontrol IC driver L293D, pada pin input 1 ,untuk pengontrolan Motor DC Sebelah kanan.

2) Port A.1, digunakan untuk mengontrol IC driver L293D pada pin input 2 untuk pengontrolan Motor DC Sebelah kanan.

3) Port A.2, digunakan untuk mengontrol IC driver L293D pada pin input 3 untuk pengontrolan Motor DC Sebelah kiri.

4) Port A.3, digunakan untuk mengontrol IC driver L293D pada pin input 4 untuk pengontrolan Motor DC Sebelah kiri.

5) Port $\mathrm{C}$,digunakan sebagai pengiriman data dan penerimaan data dari $T C P$ / IP Starter Kit atau sebagai jalur penghubung antara TCP/IP Starter Kit dengan mikrokontroler.

\section{Driver Motor (L293D)}

Pada prinsipnya Driver Motor (L293D) adalah Interface dari Mikrokontroler ke motor servo sebagai penggerak robot. Dalam penggunaannya dapat dipadukan secara langsung dengan Mikrokontroler AVR Atmega 8535 tanpa bantuan penguat. Karena dalam Mikrokontoler AVR sendiri sudah terdapat Push Pull Resistor. Tegangan referensi $+5 \mathrm{~V}$ yang merupakan output dari Mikrokontroler cukup untuk mengatur jalannya motor, dengan syarat power referensi atau tegangan referensi 
motor (Vss) didapat dari power luar bukan dari mikrokontroler sendiri, dalam perancangan ini menggunakan aki kering 6V,4,5 Ah.

Dalam penggunanya dengan memanfaatkan bit $0(0 \mathrm{v})$ dan bit $1(5 \mathrm{v})$ dari mikrokontroler AVR, driver motor L293D dapat menggerakan 4 motor sekaligus. Namun dalam perancangan ini digunakan untuk mengerakkan 2 buah motor, yang masing-masing secara terpisah dapat diatur arah putarannya Clockwise atau Anticlockwise, dengan prinsip itu maka kendali arah gerak robot dapat dijalankan sesuai dengan keinginan.

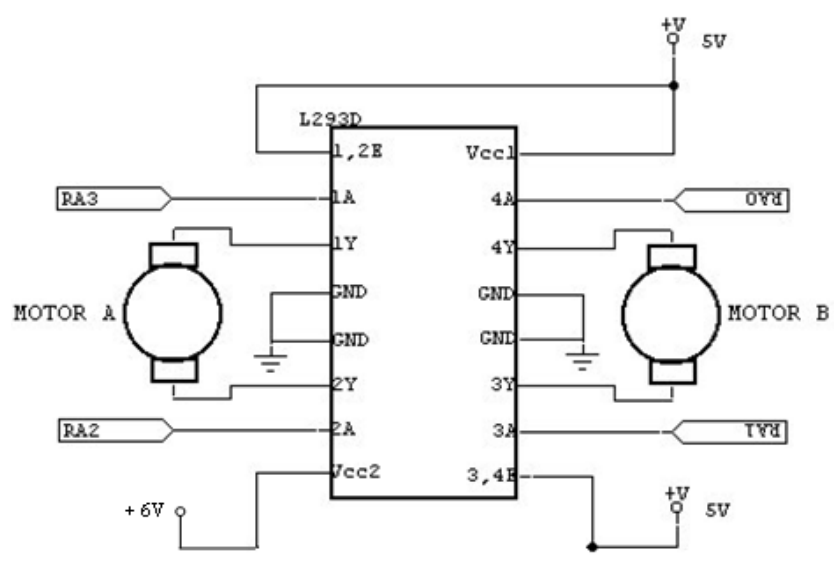

Gambar 9. Rangkaian IC Driver L293D

Dengan hanya 16 pin yang menyusun IC Motor Driver ini, tidak menggurangi fungsinya. Dengan teganggan referensi motor sampai dengan $36 \mathrm{~V}$ pada keadaan maksimum dan arus sampai dengan 1,2 Ampere, maka driver ini termasuk dapat diandalkan untuk menggerakkan motor-motor besar, ditambah tidak membutuhkan Heatsing karena mempunyai temperatur kerja -40 C sampai dengan $150 \mathrm{C}$.

\section{Perancangan Perangkat Lunak pada mikrokontroler}

Perangkat lunak pada mikrokontroler dibutuhkan untuk memberikan instruksiinstruksi pada mikrokontroler, sehingga mikrokontroler dapat bekerja sesuai dengan yang diinginkan. Dalam membuat suatu perangkat lunak / program pada mikrokontroler harus mengikuti prosedur-prosedur sesuai dengan ketentuan yang berlaku. Jadi agar mikrokontroler tersebut dapat bekerja untuk mendukung sistem peralatan seperti yang diinginkan, maka harus terlebih dahulu diisikan program yang benar, baik dari segi bahasa program maupun cara pengisiannya. Software yang 
digunakan untuk menuliskan listing program bahasa assembly adalah BASCOMAVR, alasan menggunakan software ini dikarenakan mempunyai beberapa kelebihan dibanding software yang lainnya.

\section{Memasukkan Program Kedalam Mikrokontroler}

IC Atmega8535 yang pada awalnya kosong mulai diisi dengan program. Sedangkan untuk IC yang sebelumnya telah berisi program lain, maka program tersebut dihapus terlebih dahulu secara otomatis sebelum diisi dengan program yang baru. Untuk memulainya, terlebih dahulu membuka program BASCOM-AVR yang dibuat oleh produsen mikrokontroler AT8535 tersebut yaitu ATMEL company. Kemudian memilih device yang akan digunakan yaitu AT8535.

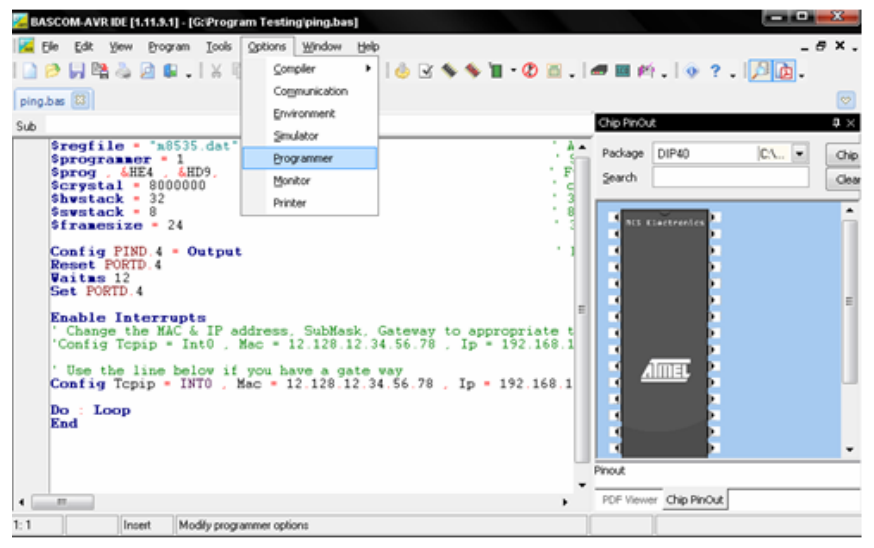

Gambar 10. Pemilihan Device yang Digunakan

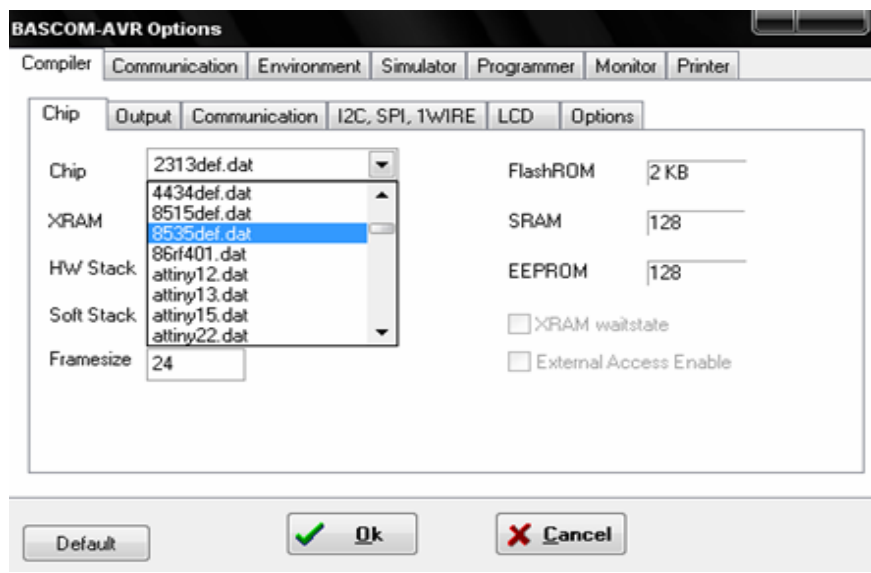

Gambar 11. Device yang Digunakan AT8535 
Tentukan device yang digunakan, pada menu "Compiler". Software kemudian meminta untuk memasukan file. HEX yang akan dimasukan kedalam IC mikrokontroler, dalam hal ini adalah ROBIN.HEX.

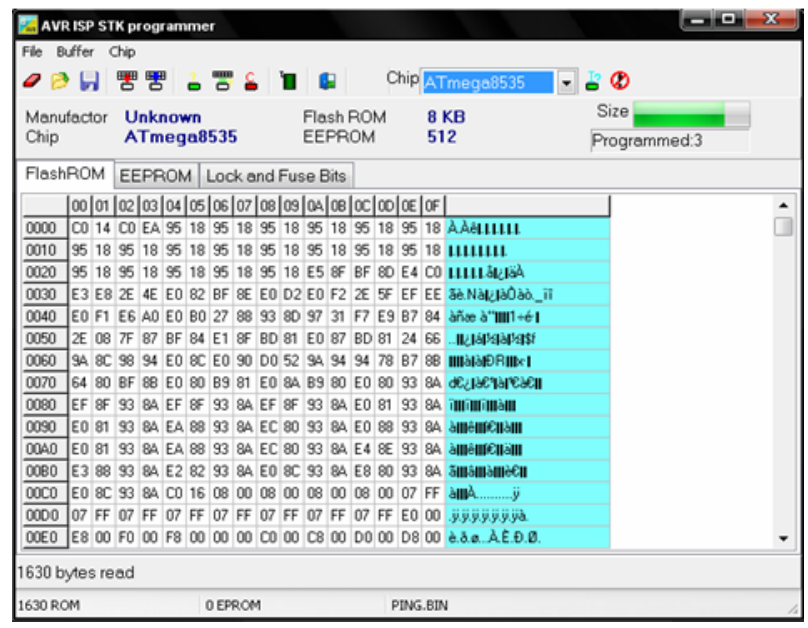

Gambar 12. Memasukkan File ROBIN.HEX

File.HEX yang telah masuk akan dikenali oleh software tersebut kemudian dimasukan kedalam IC mikrokontroler. kemudian pilih menu chip dan cari menu Auto Program.

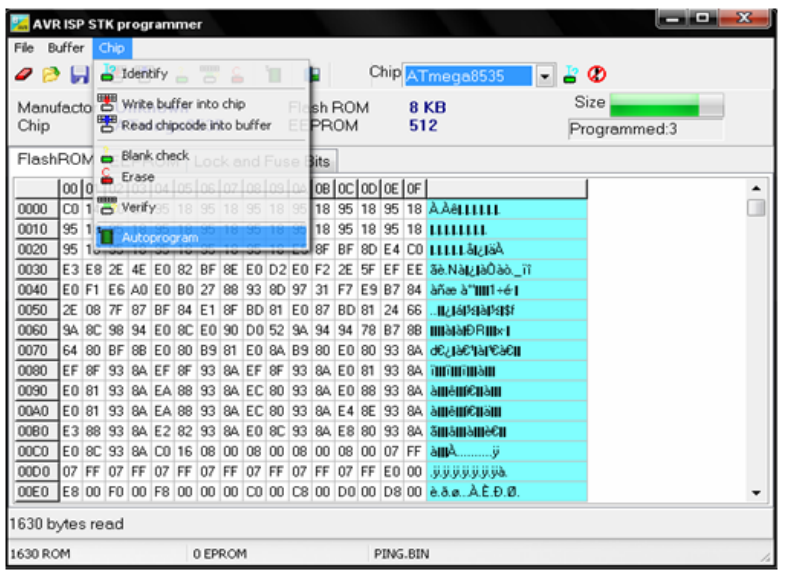

Gambar 13. Proses Pengisian IC Mikrokontroler 
ICAtmega8535 tersebut terisi seiring dengan bertambahnya presentase yang muncul pada jendela software setiap proses tersebut berlangsung. Proses pengisian berlangsung diawali dengan "Erase Flash \& EEPROM Memory", yang berarti software melakukan penghapusan terhadap memori internal IC Mikrokontroler terlebih dahulu sebelum mengisikan program kedalam IC tersebut. Pada proses penghapusan ini, apabila presentase telah mencapai $100 \%$ maka berarti memori internal telah sepenuhnya terhapus dan dalam keadaan kosong. Jika presentase belum mencapai $100 \%$ tetapi software menunjukkan tanda error, maka proses penghapusan gagal. Hal ini biasanya disebabkan oleh adanya kesalahan pada hardware downloadernya.

Setelah proses penghapusan selesai maka secara otomatis software melakukan "Verify Flash Memory". Kali ini software mulai mengisi IC Mikrokontroler dengan file. HEX. Sama dengan penghapusan, yaitu prosesnya ditunjukkan dengan penambahan presentase pengisian. $100 \%$ menunjukkan bahwa ICMikrokontroler telah sepenuhnya terisi. Dan munculnya tanda error menunjukkan proses pengisian gagal, yang biasanya disebabkan oleh kesalahan pada hardware downloadernya. Apabila langkah - langkah di atas berjalan dan selesai, maka IC Mikrokontroler yang dalam rancangan alat ini memakai jenis Atmega8535, sudah bisa digunakan untuk menjalankan sistem kerja alat rancangan.

\section{PROTOTIPE ROBIN}

Dalam perancangan "Robot IP Network yang dikendalikan melalui website", telah mengahasilkan prototipe robot yang diberi nama "ROBIN", Robot dapat di kontrol dengan baik oleh server yang terhubung secara langsung dengan ROBIN melalui koneksi jaringan wireless, ataupun oleh klien yang mengakses server melalui jaringan internet melalui URL : http://web.robin-raharja.operaunite.com .

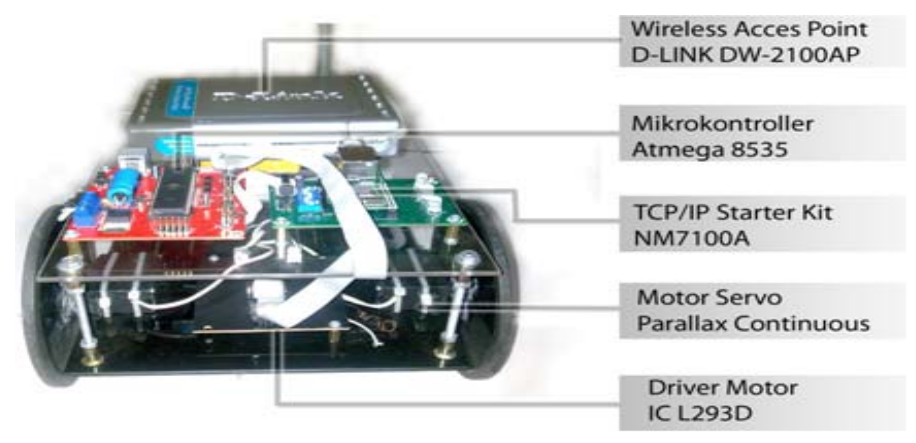

Gambar 14. Prototipe Robot "ROBIN" 
Bentuk Robot disesuaikan dengan kebutuhan ruang rangkaian komponen yang menyusun, ROBIN dibuat dua lantai untuk memudahkan dalam penyusunan dan pemasangan rangkaian. Lantai dasar bagian bawah merupakan tempat untuk baterai pada bagian belakang, untuk bagian tengah merupakan penempatan dari driver motor L293D dan motor itu sendiri. Pada lantai atas ditempatkan Wireless Access Point D-LINK DWL-2100AP, Mikrokontroler Atmega 8535 dan TCP/IP Starterkit NM7100A. Bodi Robot secara keseluruhan terbuat dari akrilik dengan ketebalan $4 \mathrm{~mm}$, agar Robot dapat kokoh menopang beban. Roda bagian depan terbuat dari akrilik $5 \mathrm{~mm}$ yang diberikan tambahan bantalan karet, sedangkan untuk roda belakang menggunakan dua buah Roller Ball Caster yang dapat bergerak kesegala arah, sehingga diharapkan pergerakan ROBIN Robot dapat berjalan dengan baik saat di kontrol melalui web server.

Pada sisi kontrol yang diletakkan di server, dibuat program web kontrol yang berbasis HTML dengan sekuriti login user. Untuk membuat server dapat di akses oleh user klien di mana saja melalui jaringan internet dibutuhkan software dan Add On dari Opera Unite. Sedangkan untuk bagian user klien hanya memerlukan tambahan software berupa web browser, dan koneksi internet tentunya untuk koneksi dengan server yang sudah di share ke internet. Perambah internet yang bisa di gunakan dalam pengontrolan seperti Internet Explorer, Firefox, Opera Browser.

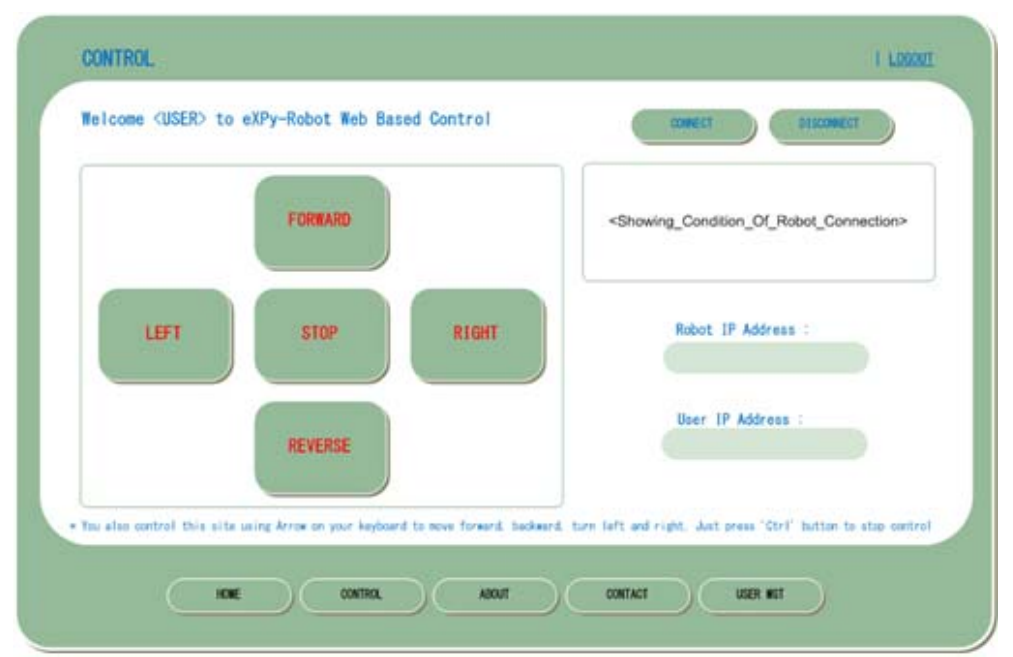

Gambar 15. Prototipe Web Server untuk Mengontrol ROBIN 
Pemilihan koneksi nirkabel dan aplikasi Web Base Control merupakan hal yang sangat penting. Konsep inilah membedakan perancangan robot ini dengan kebanyakan robot yang telah ada. Biasanya robot dibuat dengan kecerdasan tertentu. Contohnya Line Follower Robot dibuat agar robot bergerak secara otomatis mengikuti jalur yang telah ditentukan tanpa campur tangan atau kontrol dari pengguna. Berbeda dengan ROBIN tidak demikian, justru pengguna atau klien memegang peranan penuh dalam hal kontrol dan navigasi robot. Dengan begitu robot akan dapat dikembangkan ketujuan-tujuan yang lebih luas lagi.

\section{Pengujian Koneksi Client ke Server}

Pada kedua buah sisi baik Server maupun Client harus harus terhubung dengan jaringan internet secara sempurna karena jika tidak pengiriman dan penerimaan data akan tidak berjalan sempurna menyebabkan pengontrolan Robot akan sering terputus. Setelah Opera Unite pada Server di jalankan dan web sudah di share ke jaringan internet dan alamat URL sharing ROBIN http://web.robinraharja.operaunite.com, maka Server siap untuk berkomunikasi dengan Client di mana saja. Alamat share untuk Website pada Control Robot harus sesuai antara yang di Server dengan pada Client.

Dengan menggunakan koneksi internet lebih dari $768 \mathrm{Kbps}$, maka akan mendapatkan hasil yang maksimal, dan Respon yang didapatkan cukup untuk pengontrolan Robot scara baik. Sehingga untuk mendapatkan hasil yang maksimal koneksi internet harus bagus dengan kecepatan stabil.

\section{KESIMPULAN}

Dari hasil pengerjaan ROBIN yang dikembangkan oleh dosen dan mahasiswa Sistem Komputer STMIK Raharja dapat disimpulkan sebagai berikut :

1. ROBIN menjadi salah satu prototipe pemanfaatan otomasi dalam bentuk robot dengan sistem pengendalian melalui jaringan internet nirkabel (wireless internet).

2. Interface pengontrolan dilakukan melalui website untuk menggerakkan robot maju, mundur, kiri dan kanan. Web control dibuat berbasis HTML dengan Opera Unite sebagai web server.

3. Komunikasi wireless dibuat dengan memanfaatkan access point yang di tempatkan pada robot. TCP/IP Starter Kit ditambahkan sebagai penghubung antara website dengan robot yang akan menerjemahkan perintah yang dikirimkan oleh web untuk dieksekusi mikrokontroller. 
4. Komunikasi yang dilakukan oleh TCP/IP Starter Kit dan Mikrokontroller dengan menggunakan sistem $\mathrm{I}^{2} \mathrm{C}$ (Inter Integrated Circuit) yaitu komunikasi serial 2 buah IC dengan memanfaatkan dua buah pin untuk komunikasi yaitu pin data (SDA) dan pin sinyal/clock (SDL).

\section{DAFTAR PUSTAKA}

1. Asep Saefullah, (2010), Kendali Motor Industri dengan Metode Client -Server Berbasis WEB, CCIT Journal Vol.3 No.2

2. Arief Hamdani Gunawan, Andri putra, (2004), Komunikasi Data Via IEEE 802.11, Dinastindo

3. Firmansyah, B. Hermanto and L.T.Handoko, (2007), Control and Monitoring System for Modular Wireless Robot, Proc. of the Industrial Electronics Seminar 2007, Surabaya, Indonesia

4. Kalamullah Ramli, (2009), Arah Riset Sistem Tertanam (Embedded System) dan Strategi Penguatan Industri Teknologi Informasi dan Komunikasi Nasional, Pidato Pengukuhan Guru Besar, FTUI,

5. Moh. Ibnu Malik ST,(2006), Pengantar Membuat Robot, Penerbit Gava Media

6. Onno W. Purbo, (2002), TCP/IP Standar, Desain, dan Implementasi, PT Elex Media Komputindo

7. Priyambodo Tri Kuntoro, Heriadi Dodi, (2005), Jaringan Wi-Fi Teori dan Implementasi, Penerbit Andi Yogyakarta

8. http://id.wikipedia.org/wiki/Robot, diakses pada tanggal 10 Januari 2010

9. http://robot.teori.fisika.lipi.go.id, di akses pada tanggal 11 Januari 2010

10.http://www.toko-elektronika.com/tutorial/Stepper.html, diakses pada tanggal 06 Februari 2010.

11.www.atmel.com/dyn/resources/prod_documents, diakses pada tanggal 08 Fabruari 2010. 